Jurnal Psikologi Pendidikan \& Konseling

Volume 3 Number 2 December 2017. Page 1-7

p-ISSN: 2443-2202 e-ISSN: 2477-2518

Homepage: http://ojs.unm.ac.id/index.php/JPPK

\title{
Single Mothers Parenting Style In Adolescent Development: A Pilot Study
}

\author{
Ika Indrawaty Hamzah \\ School of Education and Modern Languages (SEML), College of Arts and Sciences, Universiti Utara Malaysia \\ Email: ikaindrawatyhamzah@yahoo.com \\ Fauziah Md jaafar \\ School of Education and Modern Languages (SEML), College of Arts and Sciences, Universiti Utara Malaysia \\ Email:mjfauziah@uum.edu.my
}

(Diterima: 10-Oktober-2017; di revisi: 18-November-2017; dipublikasikan: 28-Desember-2017)

\begin{abstract}
This study aims to understand the single mother parenting style in adolescent development. This pilot study involved three single mothers in Wajo District, South Sulawesi, Indonesia. Criteria single mothers were selected based on the following criteria: (1) those who are divorced, widow, separated or single parenting, and abandoned by her husband for two years which do not provide for sufficient; (2) they are the mother of their own child, and (3) they have children aged 13-15 years old. The study participants were coded to represent single mothers (SM), consisting of SM1-PS, SM2-PS, dan SM3-PS. Data were collected through in-depth interviews with the participants. The interview session takes about 20-30 minutes for each participant and interviews are recorded by voice recording device. The data gathered from semi-structured interviews were transcribed. The data analyzed using $\mathrm{N}$-vivo 11 software. The results reported two main themes are: 1) the relationship between single mother and the child, with sub-theme are: communication; 2) the single mother ways in parenting style, with sub-themes: motivation, setting rules, solving the problem, supporting children's activities, respecting children's opinions. Conclusion: The relationships between single mother and their child as well that is supported by communication with the mother. The ways that single mothers do in parenting style applies motivation, setting rules, solving the problem, supporting children's activities, respecting children's opinions. Those ways are more like authoritative parenting style. In addition, the single mothers who use corporal punishment by hitting children are more likely to cause children to run away from home and afraid to go home. In addition, the mother is firm in showing her decision to be followed by the child and no one can change it. The ways that single mothers do are more likely to be authoritarian style.
\end{abstract}

Keywords: pilot study; in-depth interview; N-vivo 11 software; single mother; parenting style.

Copyright () 2017 Universitas Negeri Makassar. This is an open access article under the CC BYNC-ND license (http://creativecommons.org/licenses/by-nc-nd/4.0/).

\section{INTRODUCTION}

Parents become the foundation in shaping a child into adulthood (Baumrind, 1971, 2013). Parents are important personalities and have a great influence on children's lives. They cultivate different attitudes, behaviors, beliefs, and values. Special attitudes and behaviors that illustrate the parenting style and have an interest in the development of children (Bibi, Chaundhry, Awan, \& Tariq, 2013). Parenting is not an easy task, especially if it is done by a single mother where the single mother are trying to fulfill the role of father and mother. According to Baumrind (2013) state that parenting style is a constelation of socialization 


\section{2 | Jurnal Psikologi Pendidikan \& Konseling Vol. 3 No.2 Desember 2017}

practices that characterize parenting techniques in managing the behavior of children. The impact of parenting style on the behavior of children is a phenomenon that requires special attention (Zaman, Arslam, Malik, \& Mehmood, 2014). More so, the influence of social development (Mensah \& Khurancie, 2014), is positively associated with the problem of child behavior either internalizing or externalizing behavior (Alizadeh, Thalib, Abdullah, \& Mansor, 2011); emotional development (ZarraNezhad, Aunola, Kiuru, Mullola, \& MoazamiGoodarzi, 2015); academic achievement (Zahedani, Rezaee, Yazdani, Bagheri, Nabeiei, 2016), school achievement (Kordi \& Baharuddin, 2010), and socioeconomic status (Smrithi \& Jeffrin, 2015). The influence parenting style continues to influence the adolescents' behavior to the adulthood. This pilot study provides an overview of recent parenting and adolescent literature such us includes new advances and directives on parenting.

\section{Typology of Parenting Style}

There are two dimensions to understand the typologies Baumrind of Parenting style (Areepattamannil, 2010; Criss \& Larzelere, 2013). In the first instance, parental acceptance/responsiveness referred to as parental warmth or supportiveness. According to Baumrind (2013), parental warmth refers to emotional warmth, support actions that are attuned to children's, vulnerabilities, cognitions, and inputs, also approving to children's special needs and plans. Secondly, parental demandingness has two components namely monitoring and confronting control. To him, monitoring refers to parents which provide structure, order, and prediction for children's lives. Control refers to parents shaping the behavior of children and maintaining an agency's expression potentially harassing children. The following illustrates the two dimensions of parenting as shown in figure 1 below:

\section{Dimensions of parenting}

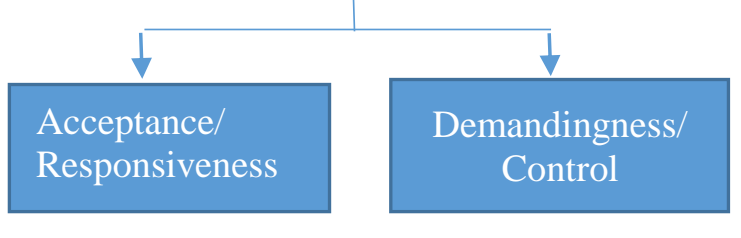

Based on these two dimensions, there are four basic parenting style: 1) Authoritarian; 2) Authoritative; 3) Permissive; dan 4) Uninvolved.

\section{Authoritarian Parenting Style}

This parenting style is very high in controlling and relying on punishment but unresponsive. They value obedience and do not tolerate giving and accepting relationships with their children. Authoritarian parents do not expect their children to express disagreement with children's decisions with their rules and expect them to be obedient without explanation (Maccoby \& Martin, 1983). Authoritarian parents are more likely to have less social competence children in dealing with other children. Frequent withdrawal from social contact and seldom take their own initiative.

\section{Authoritative Parenting Style}

The authoritative parents provide warmth and communicate with their children. They are demanding and responsive. These parents are able to stand in authority and expect the maturity of their children. They also respect the opinions of their children, giving their children freedom of expression to develop a sense of independence but know the limits of the rules that must be obeyed. This type also has high expectations for its children and uses a control in different ways (Maccoby \& Martin, 1983).

\section{Permissive Parenting Styles}

This kind is a pampering, warm and accepting parent but their primary concern does not interfere with the creativity and independence of their children. They are more responsive than demanding. In fact, they demand little in terms of obedience and respect for authority. Also, they are not traditional and soft, require no maturity, allow enough selfregulation, and avoid confrontation (Maccoby \& Martin, 1983).

\section{Uninvolved Parenting Style}

Uninvolved parents are not involved both responsively and demands. Both type of parenting style reject-ignore and ignore parents. Parents of this type of parenting do not build rules toward their children even if they do not care about the direction of their child's behavior (Maccoby \& Martin, 1983). 
Single Mother' Parenting Style

Parenting has been demand physically, emotionally, and financially, especially single mothers. There are several reasons to make someone as a single mother. For Example, death (widows), separated or divorced (Hew, 2003). Single mother parenting style is varied according to their circumstances. Based on the opinion of Lamb and Baumrind (1978) describes the relationship between parenting style and the development of the child's personality. Furthermore, Baumrind focuses on four aspects of parental behavior, strictness, the demands of children to attain maturity, intellectual, emotional, and social, communication skills, warmth and involvement (Baumrind, 1978). According to Kiernan and Mensah (2010), children born to single mother show a high level of social problems associated with lower levels of economic loss and poor mental health and health and increased behavioral problems. This related to the opinion of Amato (2000, 2001, \& 2005), the single mother of divorce demonstrating emotional and behavioral problems for her children. Furthermore, single parents have little time to monitor or supervise their children (Copeland, 2010; O'Connor \& Scott, 2007; Roska \& Potter, 2011; Thwala, 2011). Cavanagh \& Fomby (2012) state that children from single parents also communicate less. Likewise, children are more likely to suffer deprivation and rejection of some rights and opportunities (Crosnoe, 2007). The findings show that not a few children show risky behaviors such as smoking, drinking, delinquency, violence, social activity, unsafe sex and suicide attempts (Symeon, 2007).

\section{METHOD}

The selection of participants in this qualitative study is based on non-probability sampling where the researcher chooses individuals because "they are willing, easy, comfortable and representative of some of the characters that researchers are trying to learn (Creswell, 2012).

For this pilot study, the researcher uses purposive sampling to select single mothers as participants for research through consideration based on criteria: (1) divorced, widow, separated or single in parenting, and abandoned by husbands for 2 years who do not give sufficient living; (2) they are the mother of their own child; and (3) they have children aged 13-15 years old.

For this pilot study, there are three single mothers selected as participants. The researcher used codes that represent single mothers (SM), consisting of SM1-PS, SM2-PS, and SM3-PS. The purpose of using this code is to make participants more comfortable in answering interview questions. The Interview questions using Indonesian language. The interview sessions were recorded to assist the researcher in transcribing interview results. Answers from participants will help the researcher find themes or categories that may appear in actual research and refine interview questions when needed. An interview on the pilot study is used to familiarize in interview techniques and questions in making sure that interview questions are clear and understandable as well as creating a good environment for participants to answer the question posed (Creswell, 2012).

Data collected through in-depth interviews with three participants. Interview sessions are conducted face-to-face with the participants. This type of in-depth interview is to understand in detail the single mother parenting style in adolescent development. Interview sessions run around 20-30 minutes and interviews are recorded by voice recording device. The data gathered from semistructured interviews was transcribed. The data analyzed using N-vivo 11 software (Tobi, 2016).

\section{RESULTS AND DISCUSSION}

There are two main themes identified and described as follows:

Theme 1. The relationship between single mothers with the child

The three participants reported that the relationship with their children well established. Their relationship is built based on communication with the child. Although the mother works, she takes the time to communicate by telephone. Even during school holidays or other days such as Friday and Saturday. In addition, communication between mother and child also takes place more open and affectionate, the child is free complains and communicate with the mother. This is in accordance with the following participant's described: 
My relationship with my son is fine. I gather with him outside working hours and more time at night. (SM1-PS)

I am with my son interconnected even though I work out of town but took the time to contact the child by phone. Sometimes I go home early to meet the kids. Even during school holidays

Theme 2. The single mother ways in parenting style

In describing how single mother ways in parenting style, single mothers are more likely to direct their children to the educational aspect. For example, children may be free to go out but the main thing is to go to school and not drop out of school. Single mother motivates children to learn in the hope of being successful even without a father at home. This is in accordance with the following participant's explanation:

"I do not forbid to go out, to school in the morning, then come home to play, which is important you do not drop out of school. (SM1-PS)

I motivate my children. I said" your father now with us anymore here, so be diligent to learn to be clever". (SM2-PS)

In addition, some direct their children by not pressing and imposing their will on their child and give confidence to the child. This is in accordance with the following participant's explanation:

I never put pressure on the child and give confidence to the child. I said" I trust you and you have to keep that trust". (SM3-PS)

In everyday life, participants set the rules at home, but not as free and not burdensome to the children. Rules are consisting to be home on time to study and play and the children are prohibited to perform negative behaviors Participants are assertive to their children when they involved in negative behavior at school, such as skipping schools based on teacher reports received from the school and always hanging out with school dropouts. Single mother assumes the child has changed but still repeat the behavior. In dealing with the problem, the and other days like Friday and Saturday, I go home (SM2-PS).

The relationship with my child is good, open to each other with the child's affection and detailing what is there. My child is free to complain, free to communicate. I also consider the child like a brother and always be open (SM3-PS)

mother often counseled her child. However, some child is stubborn and difficult does not to listen to his mother. Sometimes the mother scolds the child for negative behavior and used physical punishments, however this cause the child to run away from home and be afraid to go home. Therefore, the mother changed the way and stopped beating. This is in accordance with the following participant's explanations:

"I stopped hitting my son because by the time I hit him but ran away from home. At 21.00 pm I found and he was afraid to go home. So this way is not good for me. (SM1-PS)

In addition, there are negative things done by the child such as do not respond when called, do not ask permission to go out of the home. The participants reveal that she would feel unease when there is a problem with her son. She would call her to give advice or motivate not to repeat his actions. However, at school, the child has no problem and his actions are still under control. This is in accordance with the following participant's explanations:

Making mistakes is rarely done, I am also
not difficult and not easy because children
are obedient to the rules at school. But if I
make a mistake, then I just counsel and
teach to improve his behavior. (SM2-PS)

Participants sometimes use assertiveness in dealing with their child's behavior such as a child fights with a sister. Assertiveness is also expressed when a single mother says "no" then does not change then does not change that decision. Anyone cannot change and must be followed. This is accordance with the following participant's explanations: 
I am very firm with my children. If I say "no" it does not change that decision and anyone cannot change it and must follow. (SM3-PS)

In terms of expressing opinions, the participants always provide opportunities their children to express and respect the children's opinions. For example, when the child asked for football to play soccer with his friends. His mother would ask him to be patients. In fact, some of the participants provide a space to complain of problems faced by children. This is in accordance with the following participant's explanations:

My son says "mom, buy the ball for me, I am not included in a soccer game if I don't have a ball". (SM1-PS)

If my child has a desire to buy and there is no money something and I do not have the The Model of Study money yet, I say "be patient", no money yet. (SM2-PS)

Therefore, participants also do not restrict their children and provide opportunities to support activities such as sports, art, and other activities. This is in accordance with the following participants' explanations:

I tried to buy the ball because my child has a hobby in the sport. In the afternoon he is playing football. (SMI-PS)

Well, my child is active in scout, drum band and other activities school. I still give permission for his school activities. (SM2$P S)$

I support my child's activities. For example participate in scout activities at school (SM3$P S)$

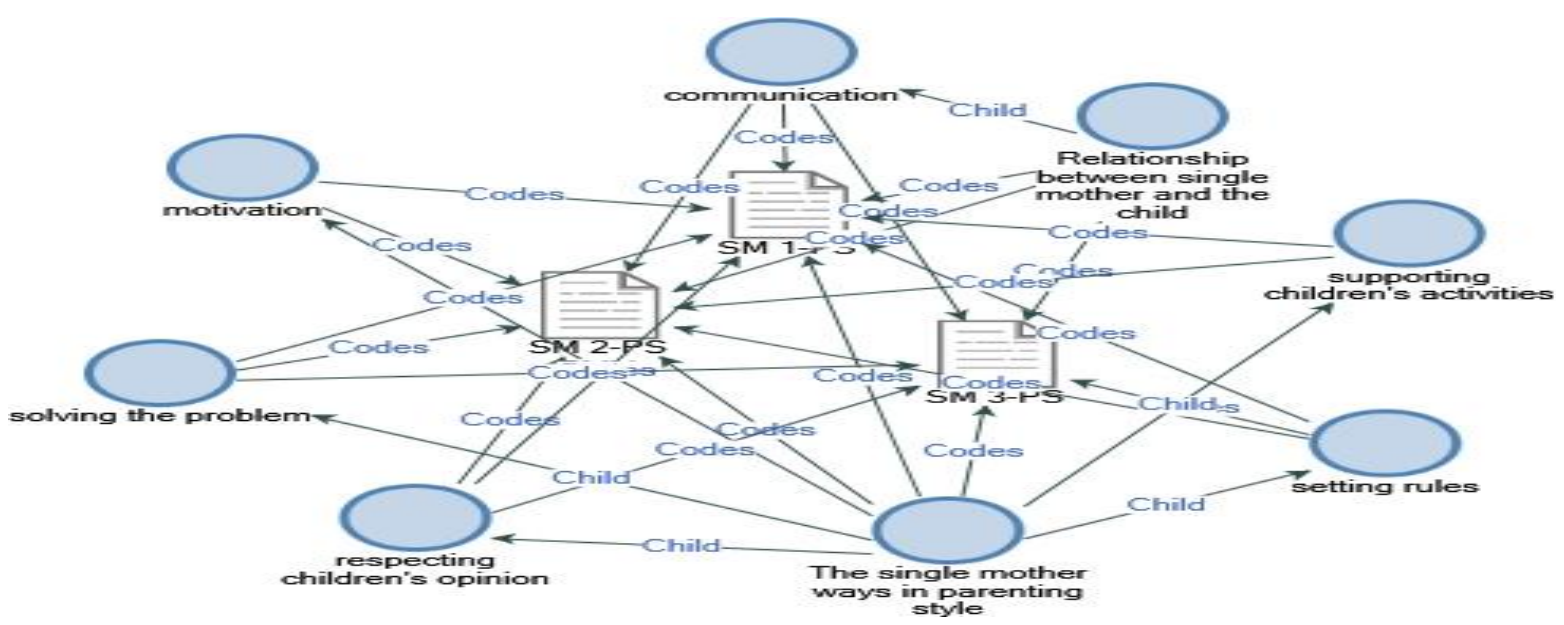

\section{CONCLUSION AND SUGGESTION}

This pilot study reported some findings. First, the three participants explain the relationship between mother and child as well that is supported by communication with the mother. The mother always takes time to communicate with her child at home. Second, single mother ways in parenting to their children by directing the child educational aspect such as directing to school and motivating in learning to become a successful person. Participants set rules at home but do not provide freedom based on the will of the child and do not burden the children. In general, participants rebuked or scolded the child for negative behavior. In terms of expressed the opinions, the participants provide an opportunity to express and respect their child's by responding to be the child's demands and providing opportunities to support their activities in the school with positive activities. Those ways that single mothers do are more likely to be the authoritative parenting style. Participants are assertive when their children skip school so they use physical punishment by hitting a child that causes a child to run away from home. In addition, the mother 
asserts herself by showing the decision to be followed by the child and no one change it. The ways that single mothers do are more likely to be the authoritarian parenting style.

Suggestion. Single mothers are expected to understand the development of their child applying a good parenting style according to the child's development, especially adolescents.

\section{REFERENCES}

Alizadeh, S., Thalib, M.B.A., Abdullah, R., \& Mansor, M. (2011). Relationship between parenting style and Children's behavior problems. Asian Social Science, $7(12)$. doi.10.5539/ass.v7n12p195.

Amato P. R. (2000). The consequences of divorce for adults and children. Journal of Marriage and the Family, 62, 12691287.

$10.1111 / \mathrm{j} .1741-$ 3737.2000.01269.x.

Amato P. R. (2001). Children of divorce in the 1990s: An update of the Amato and Keith (1991). meta-analysis. Journal of Family Psychology, 15, 355-370. 10.1037/0893-3200.15.3.355.

Amato P. R. (2005). The impact of family formation change on the cognitive, social, and emotional well-being of the next generation. The Future of Children, 15, 75-96. 10.1353/foc.2005.0012.

Baumrind, D. (1985). Familial antecedents of adolescent drug use: A developmental perspective. In C. L. Jones \& R. J. Battjes (Eds.), Etiology of drug abuse: Implications for prevention NIDA Research Monograph No. 56, pp. 13-44; DHHS Publication No. (ADM) 851355). Rockville, MD: National Institute on Drug Abuse.

Baumrind, D. (1991). The influence of parenting style on adolescent competence and subtance use. Journal of Early Adolescence, 11, 56-95.

Baumrind, D. (2013) Authoritative parenting revisited: history and current status. In R.E. Larzelere, A. S. Morris, \& A. W.
Harrist (Eds.), Authoritative parenting: synthesizingnurturance and discipline for optimal child development. Washington, DC: American Psychological Association. Pp. 11-34.

Bibi, F., Chaundhry, A.G., Awan, E.A., \& Tariq, B. (2013). Contributing of parenting style in life domain of children. Journal of Humanities and Social Science, 12(2): 91-95.

Cavanagh, E. S., \& Fomby, P. (2012). Family instability, school context and the academic careers of adolescents. Journal of Sociology in Education, 85(1): 81-97.

Criss M. M., \& Larzelere, R. E. (2013) Introduction. In R. E. Larzelere, A. S. Morris, \& A. W.Harrist (Eds.), Authoritative parenting: synthesizing nurturance and discipline for optimal child development. Washington DC: American Psychological Association. Pp. 3-8.

Creswell, J. W. (2012). Educational research: Planning, conducting and evaluating quantitative and qualitative research (4th Ed.). Boston, M.A : Pearson Education Inc.

Copeland, D. B. (2010). Psychological differences related to parenting infants among single and married mothers. Issues in Comprehensive Pediatric Nursing, 33: 129-148.

Crosnoe, R. (2007). The connection between academic failure and adolescent drinking in secondary school. Austin, USA: University of Texas at Austin.

Darling, N., \& Steinberg, L. (1993). Parenting style as context: An integrative model. Psychological Bulletin, American Psychologycal Association, 113(3), 487-496. http://doi.org/10.1037//00332909.113.3.487.

Hew, C.S. (2003). The impact of urbanization 
on family structure. The experience of Serawak, Malaysia. SOJOURN. Journal of Social Issues in Sotheast Asia, 18, 89109.

Kiernan K., \& Mensah F. K. (2010). Unmarried parenthood, familytrajectories, parent and child well-being. Bristol, UK: The Policy Press.

Kordi, A., \& Baharuddin, R. (2010). Parenting attitudes and style and its effect on children's school achievement. International Journal of Psychological Studies, 2(2): 217-222.

Lamb, M.E., \& Baumrind, D. (1978). Socialization and personality in the prescohooltears. In M. E. (Lamb (Ed), Social and personality development ( $\mathrm{pp}$. 50-69). New York: Holt, Renehart and Winston.

Maccoby, E. E., \& Martin, J. A. (1983). Socialization in the context of the family: Parent-Child interaction. In P.H. Mussen (Ed). Handbook of Child Psychology, 4, 1-101.

Mensah, M. K., \& Kuranchie, A. (2013). Influence of parenting styles on the social development of children. Academic Journal of Interdisciplinary Studies, 2(3): 123-129. doi: 10.5901/ajis.2013.v2n3p123

O'Connor, T. G., \& Scott, S. B. C. (2007). Parenting and outcomes for children. York, United Kingdom: Joseph Rowntree Foundation.

Roska, J., \& Potter, D. (2011). Parenting and academic achievement: Intergenerational transmission of educational advantage. Journal of Sociology in Education, 84: 299-318.

Smrithi, S., \& Jeffrin, M. (2015). Influence of socio-economic status and parenting style on academic accomplishment and adjustment among college students. Indian Journal of Health and Wellbeing, 6(10): 1019-1021.
Symeon, L. (2007). Cultural capital and family involving in children's education: Tales from primary schools in Cyprus. British Journal of Sociology in Education, 28(4): 473-487.

Texas at Austin.

Thwala, S. (2011). The psychosocial world of orphans and vulnerable children: The implications of psychosocial support for orphans and vulnerable children in Swaziland. Germany: VDM Verlag Dr.

Tobi, S.U.M. (2016). Qualitative Research, Interview Analysis and Nvivoll Exploration. Kuala Lumpur Malaysia: Aras.

Zahedani, Z. Z., Rezaee, R., Yazdani, Z., Bagheri, S., Nabeiei, P. (2016). The Influence of parenting style on academic achievement and career path. Journal of Advances in Medical Education \& Professionalism, 4(3): 130-134. I

Zarra-Nezhad., Aunulo., Kiuru., Mullula., \& Moazami-Goodarzi. (2015). Parenting styles and children's emotional development during the first grade: The moderating role of child temperament. Journal Psychology \& Psychotherapy, 5(5): 2-12. doi: 4172/2161-04871000206.

Zaman, R., Arslam, M., Malik, R.K., \& Mehmood. (2014). Effect of parenting style on child behavior: A Qualitative Analysis. Journal of Education and Practices, 5(26): 112-118. 